\title{
Note from the Book Review Editor / Note de la responsable des recensions
}

As 2020 thankfully draws to a close, we have a moment to reflect on events and on how time has been both stretched and compressed by everything that has happened in the pandemic and that intersects with it. Appositely, one of the books reviewed in this issue focuses on lived experiences of time and how it shapes and is shaped by gendered subjectivity. This year has also been marked by the growing strength of the Black Lives Matter movement, which began in the United States but is now a global political and social force; our second book under review concentrates on understanding the phenomena of race and racism. In the context of closed borders, lockdowns, and stay-at-home orders, our third book under review seems almost like a fantasy, as it is a chronicle of a carefree European summer of hitchhiking and love, although politics is important here too.

The first book, Megan Burke's When Time Warps: The Lived Experience of Gender, Race, and Sexual Violence, is reviewed sensitively by Fiona Vera-Gray, a sociologist who researches harassment, violence, and existential phenomenology. ${ }^{1}$ The Second Sex is an important text for this work, and Burke mines Beauvoir's account of our gendered relationship to time as a temporality of waiting and of a horizon of sexual violence. ${ }^{2}$ Vera-Gray explores and questions the connections Burke draws between feminine existence and the legacy of colonization.

Michael Eng's work concerns the aesthetics of subjectivity in relation to race, gender, and disability; his review of Emily S. Lee's edited collection Race as Phenomena: Between Phenomenology and Philosophy of Race is our second. ${ }^{3} \mathrm{He}$ compares this volume to her other edited book, Living Alterities, seeing it as a continuation of the problem of accounting for the enduring interpretation

1 Fiona Vera-Gray, The Right Amount of Panic: How Women Trade Freedom for Safety in Public, Bristol, UK, Policy Press, 2018, and Men's Intrusion, Women's Embodiment: A Critical Analysis of Street Harassment, Abingdon, UK, Routledge, 2016.

2 Simone de Beauvoir, The Second Sex, trans. Constance Borde and Sheila Malovany-Chevalier, New York, Knopf, 2010 [1949].

3 Michael Eng and Dan Bucsescu, Looking beyond the Structure: Critical Thinking for Designers and Architects, New York, Fairchild Books, 2009. 
of race as natural. ${ }^{4}$ Eng's review interrogates the essays' descriptions of lived experience to consider the limits and biases of phenomenology.

Tiphaine Martin's expertise lies in travel-writing, especially that of Beauvoir. ${ }^{5}$ She reviews Blossom Margaret Douthat's epistolary volume, Un amour de la route. Lettres à Simone de Beauvoir, août-octobre 1958 (Love on the road: Letters to Simone de Beauvoir, August-October 1958). The connection between Douthat, an American student, and Beauvoir shows the profound effect of reading Beauvoir's work and of meeting her personally. Martin's review stresses the writerly and theatrical character of the letters and how that character inflects Douthat's description of her love affairs and political views.

These works suggest that Beauvoir's phenomenological approach has resources that need to be further developed, particularly in relation to the experiences of time and race, and that Beauvoir's relation to her readers and the fields of autobiography and travel-writing has much room for further exploration.

\section{Marguerite La Caze}

University of Queensland, St. Lucia, Brisbane, Queensland, Australia m.lacaze@uq.edu.au

4 Emily S. Lee, ed., Living Alterities: Phenomenology, Embodiment, and Race, Albany, State University of New York Press, 2014.

5 Tiphaine Martin, "Réécrire L'Écolier d'Athènes. Simone de Beauvoir et le voyage autobiographique," in Paschal Grousset. Éducation et littérature pour la jeunesse, ed. Pierre-Alban Lebecq, Reims, Épure, 2020, pp. 331-342. 